\title{
THE EFFECTIVE OF USING SQR3 METHOD IN STUDENT'S READING COMPREHENSION
}

\author{
${ }^{(1)}$ Hijril Ismail, ${ }^{(2)}$ Bulan Purnama Jingga \\ (1) Lecturer of English Department University of Muhammadiyah Mataram \\ (2) Student's of English Department University of Muhammadiyah Mataram
}

\begin{abstract}
This study focused on the analysis of the effectiveness of applying SQR3 method in student's reading comprehension at the second year students of MA At-tahzib Gunung Sari in academic year 2015/2016. It was aimed at answering the research question 'Is SQR3 method effective in teaching student's reading comprehension?' The population of this study was the grade XI students of MA At-tahzib Gunung Sari. The sample of this study was the students of class XI IPA 1 (experimental group) and XI IPA 2 (control group) with the total sample 52 students from both classes. The writer conducted the research starting from giving pre-test, treatment and post-test. In the process of treatment, both group were treated differently. The experimental group was treated by using SQR3 method,while the control group was not treated by using SQR3 method. Based on the finding, it was suggested that SQR3 method can be used by the English teacher as a method in teaching,especially in teaching reading. The result of the test showed that the mean score of the experimental group was 25.07 which was higher than the mean score of control group (9.65). It was also supported by the t-test (6.85) which was higher than t-table at the confidence level of .05 (95\%). Therefore, the alternate Hypothesis (Ha) which stated"SQR3 method is effective in teaching student's reading comprehension" is accepted. It means that SQR3 method is effective in teaching student's ability in reading comprehension for the second year students of Ma-Attahzib Gunung Sari in academic year 2015/2016.
\end{abstract}

Key words: $S Q R 3$ method,reading comprehension. 


\section{INTRODUCTION}

Reading becomes a daily routine for every one who always wants to access information. Through reading, people may improved their knowledge and experiences especially for someone who are in process of learning. It can help them in expanding their knowledge and enriching their vocabulary. Therefore,reading is one of the four skills that have to be taught in language classroom.

In Second language context,reading comprehension is known as a highly complex skill to be mastered (Phakiti,2006). New vocabulary and different text structure may cause the difficulties to foreign language learners to master reading text. That is also the main challenge for many students of ESL. As stated by Clarston (2011), one of the barries to master reading comprehension is student's inability to engage the text when they are reading. Ineffective reading may cause the students to find difficulties in comprehending the text.

The writer argues that most students at all level of education obtain the difficulties in comprehending reading. Moreover, if we ask them whether they like reading in English written text or not, their answer tend to be mostly negative. The beginner of English students who learn to read in English usually don't like it and the time they spend reading is very limited.

Speed reading method namely SQR3 is one of the important strategies to improve reading skill. It is often use to help someone to make their reading more effective and efficient.According to Robinson (1991) from the University of United States, from book of "Effective Study" SQR3 is a method for active elaboration of material that you read, say in textbook. Steps of SQR3 the acronym SQR3 stand for the step that student follows in using the method: Survey ,Read, Question, Recite, Review.

The Survey-Question-Read-Recite-Review (SQ3R) method is perhaps one of the oldest and most widely implemented study strategies (Lipson \& Wixson, 2003). The SQ3R method applies most readily to textbooks and formal reading assignments in which readers are required to consume main points from expository writing.

A number of studies on the use of SQR3 method have been conducted. Puspitasary (2011) on "The effect of Using SQR3 Technique Towards Reading Comprehension ability for second year student of SMPN 1 Bodeh Pemalang" involved two groups of 60 students , 30 students in experimental group and 30 students in control group. The experimental group was tought with SQR3 technique and the control group was treated without SQR3 technique. The writer used a multiple- choice reading test as the instrument of the research and the test takes 45 minutes to do. The result showed that t-ratio is higher than the t-table ( $3.5769>$ 2.000). This study concluded that SQR3 technique gives positive effect toward student's reading comprehension ability.

In line with Puspitasari, research carried out by Mauidhatul hasanah (2012) on " The Effectivenes of SQR3 method in Reading comprehension in the second year of SMAN 1 Suralaga " involved two groups of students. The experimental group was tought with SQR3 method and the control group was treated without SQR3 
technique. The result showed that the mean score of the experimental group is 18.88 which is higher than the mean score of the control group and 7.27. The t-tes is 2.56 which is higher than the $\mathrm{t}$-table Based on the data, it can be concluded that $(\mathrm{t} o>\mathrm{tt})$. So, the SQR3 Method is effective to improve student's reading comprehension for the second grade of SMAN 1 Suralaga.

From the previous studies above, the use of SQR3 method can influence students reading skill, SQR3 can be an effective technique in improving reading comprehension, but sometimes we can also find the result that using this technique is not really effective for improving student's reading comprehension. From those statements, the writer would like to conduct a research about how SQR3 method may influence the student's reading comprehension, the writer decided to evaluate the effectiveness of SQR3 method in teaching reading at Ma Attahzib Gunung Sari . Related to the students in comprehending the text, SQR3 method seems to be a potential solution as it provides the students with a structured reading strategy which can help them comprehend the text.

The research question of this study is formulated as: Is SQR3 method effective in teaching student's reading comprehension at the second year students of MA At-tahzib Gunung Sari in academic year 2015/2016?"

\section{REVIEW OF RELATED STUDY}

\section{Reading Concept}

The major function of language is a means of communication. To be able to communicate with other people,language learners should have and use four language skills (listening,writing,reading and speaking ).

Talking about listening skill ,this skill is vital for learners. In term of the four listening skills, listening skill is the most frequently used. Listening and speaking are often taught together, but for beginners especially the non - literate ones, should be given more listening than speaking practice.

Talking about speaking skill,speaking is the main goal of learners. Learner's personalities play a large role in determining how quickly and how correctly they will accomplish this goal. The student who are risk - takers unafraid of making mistakes will generally be more talk active. On the contrary, shy students may take a long time to speak confidently, but when they do that their English contains fewers errors and they will be proud of their English ability.

The third skill is writing skill. Good writing conveys a meaningful message and uses English well,but the message is more important than correct presentation. The last one is reading skill. Reading is one of the most important skill in learning language besides listening, writing and speaking. The fundamental of any reading activity is knowing enough science concepts and knowing the language (i.e.comprehending/ understanding). 
Reading is one sub area of English language that is thought in educational at indonesian school today. To improve their learning ability, English teachers should be use meaningful reading materials to simplify their students to understand the materials easily.

Reading is a skill in English that focuses on recognition of written symbols. The students must attempt to identify the writing form by analyzing the whole parts. Reading is a means of language acquisition,communication, and sharing information and ideas. It is aimed for the students to be able to reach and investigate any reading material problems by themselves using their potency and ability. In guiding students to do that,it is better for them to know some aspects of reading; they are mechanical and comperehension skills.

According to Tarigan (1979, in Lail 2003:10) mechanical skill is considered as a lower order. This aspect consists of: (1) Recognizing the letter, (2) Recognizing the linguistics elements such as phonemes and sentences (3) Recognizing the relationship between syllable and sound to bark (4) The speed of lower reading rates. Furthermore, Broughten in Tarigan (1979, in Lail 2003:10) points out the comperehension skill which is considered as a higher level order consisting of several elements: Understanding simple meaning (lexical, grammatical and rhetorical), understanding significance or meaning, evaluation of the content and style, the flexibility of reading speed.

Based on the explanation above, it is appropriate enough for writer to take her experiment in senior high school, remembering that reading comperehension itself for higher level of students.

\section{Kinds of Technique in Teaching Reading}

Specifying in teaching reading, teacher who teaching reading in the classroom must have the techniques applied in the teaching of reading skill.. So, the teacher must have the techniques that understood by the students in the classroom. There are some techniques in reading :

\section{Jigsaw Reading}

(Harmer : 2007) said that there are some ideas teacher can apply in teaching reading, especially in intensive reading. They are: reading squences, reading strategies, by any other techniques,such as jigsaw reading, reading puzzle,by poetry. But this essay will only explain about the reading squences and reading strategies .

According to Aronson (2008) there are ten steps considered important in the implementation of the jigsaw classroom:

- Students are devided into 5 or 6 person in a jigsaw group. The group should be diverse in terms of ethnicity, gender, ability and race.

- One student should been appointed as the group leader. Those persons should initially be the most matter student in the group

- The day's lesson is divided into 5-6 segment (on for each member) 
- Each student is assaigned one segment to learn. Student should only have direct access to only their own segment.

- Student should be given time to read over their segment at least twice to become familiar with it. Students do not to memorize it.

- Temporary experts group should been formed in which one student from each jigsaw group join other student assaigned to the same segment. Students in this expert group should be given time to discuss the main points of their segment and rehearse the presentation they are going to make to their jigsaw group.

- Student come back to their jigsaw group

- Student present his or her segment to the group. Other members are encouraged to ask question for clarification.

- The teacher needs to float from group in order to observe the process. Intervene if any group is having trouble such as a member being dominating are disruptive. There will come a point that group leader should handle this task. Teacher can whispers to the group leader as how to intervene untill the group leader can effectively do it themselves.

- A quiz on the material should been given at the end so students realize that the seassions are not just for fun and games but they really count.

\section{K-W-L- Chart}

K-W-L is created by ogle (1986). K-W-L Chart is a 3-column chart that helps capture the Before, During and After components of reading a text selection.

a. K stands for Know

This is the prior knowledge activation question.

b. W stands for Will or Want

What do i think i will learn about this topic?

What do i want to know about this topic?

c. $\quad$ L stands for Learned

What have i learned about this topic?

\section{Elicting Personal Response}

Elicting personal response means teacher ask some questions that require students to respond the text and relate it with their own experience or feelings.

Doff (1998, in Satriawan 2010) pointed some activities in elicting personal response :

1. Asking students to match what they read against their own experience.

2. Asking students to imagine themseleves in a situation related to the text but beyond their own experience.

3. Asking students to express feelings or opinions.

\section{SQR3 Technique}


This technique is introduced by Robinson (1941), where SQR3 stands for survey, Questions, Read, Recite and Review. SQR3 becomes a method when it is a planned way of doing something. Teachers usually use it in different techniques. The writer tries to choose the last one (SQR3), because she thinks that this technique is appropriate for her research in reading comprehension.

\section{SQR3 as Method in Reading Comprehension}

SQR3 method is a reading comprehension method named for its five steps: survey, question,read,recall, review. The method introduced by Francis Pleasant Robinson in his 1946 book Effective study. Young (2007) define SQR3 is one strategy for reading comprehension that helps students understand the meaning an the organization of textbook reading.

\section{- Survey}

Survey in this method is to get an overall picture of what we are reading. In this case ,we look at the title , subheading, illustrations,grasps ,charts, map, etc. This will help us to know where we are going and also how the author has organized his materials. Furthermore, before we start to read the chapter or text,we look at the final couple of paragraphs, which way include the summary, and which will very likely repeat the major ideas of the chapter . if the material is completely new to use, we can spend a time reading the first couple of the sentence of each new topic. So we can gain overall picture of the content.

\section{- Question}

The question step will help us to focus the mean ideas and supporting details in each section, and to tie this information with what we already known. Moreover, lots of modern textbooks have question at the end of each chapter we will be looking for answering to them, and also we will know what to concrete on.

- Read

While reading, we concentrate in answering the question we have in mind in relation to the topic. In this section we concentrate in mastering main idea and significant details of the material. Slowing up our reading in the importance of the materials is also has to be thought. The activities that are not expected to do are : do not make a note, do not make a sign or mark and underline in order to avoid inappropriate marker.

- Recall

In this step, we try to make note on what we have read. Most readers found that note taking in a great will helps us in getting information fixed in the mind. If we can outline the chapter which we have finished reading, than we really know what we have read. Finally, we have useful summary whenever we want to review the reading pessage.

- Review

The ability to recall something is very limited. Soedarsono (2004) says that even though when we read the material we master it $85 \%$, but 8 hours later our memory 
becomes $40 \%$ and than 2 weeks later it beecomes $20 \%$. To overcome this problem it's better for us to re-read the important part of the material that we have already raed. It will lead us to find out important part that we have evoke. It also will help us to clarify our comprehension about the material and find important part that is lost in our previous reading.

\section{Procedure of SQR3 method in Teaching}

There are some procedures in teaching reading by using SQR3 method as follows:

- The teacher should start the lesson by activating prior knowledge.

- In the first step of strategy, that is "surveying",the teacher should guide students to survey the text by skimming the text to get the key words and the main ideas.

- In the second step, that is "questioning", the teacher should guide students to generate the question based on the key word and main ideas acquired in the previous step.

- In the third step, that is "reading", the teacher should guide students to get the detailed information of the text,reminding them to get the answer to their own questions, and not to let them write notes during this step.

- In the fourth step of the strategy, that is reciting, the teacher should guide students to write a note and the answer to the questions that have been generated in "questioning"step, and not to let them open the text again.

- In the fifth step, that is "review", the teacher should guide the students to review the text and help them to find whether there is any missing information during the first reading season.

After knowing some steps of SQR3 method, it is better to know some advantages and disadvantages of this method. some advantages of SQR3 method are

- It makes reading more active

- It improves understanding of reading assignment

- It provides structure and a plan of action

- It provides a sense of control over reading assignments

- It enhances remembering and recalling new information from memory

- It helps maintain attention

- It is easy.

Beside it's advantages, SQR3 also has disadvantages. One of the disadvantages is that it can add 10 to $15 \%$ more time for a study session.

\section{Studies on SQR3 for Reading comprehension}

Many studies have focused on the use of SQR3 technique to teach reading. First , study conducted by Puspitasary (2011) on "The Effect of Using SQR3 Technique Toward Reading Comprehension Ability for Second Year Students of SMPN 1 Bodeh Pemalang" involved two groups of 60 students , 30 students in experimental group and 30 students in control group. The experimental group was tought with SQR3 technique and the control group was treated without SQR3 
technique. The writer used a multiple- choice reading test as the instrument of the research and the test takes 45 minutes to do. The result showed that t-ratio is higher than the t-table $(3.5769>2.000)$. This study concluded that SQR3 technique gives positive effect toward student's reading comprehension ability.

Second, research carried out by Mauidhatul hasanah (2012) on "The Effectivenes of SQR3 method in Reading comprehension in the second year of SMAN 1 Suralaga " involved two groups of students. The experimental group was tought with SQR3 method and the control group was treated without SQR3 technique. The result showed that the mean score of the experimental group is 18.88 which is higher than the mean score of the control group and 7.27. The t-tes is 2.56 which is higher than the t-table Based on the data, it can be concluded that $(\mathrm{t} o>\mathrm{tt})$. So, the SQR3 Method is effective to improve student's reading comprehension for the second grade of SMAN 1 Suralaga.

From the data above, the researcher concluded that SQR3 can be an effective technique in improving reading comprehension, but sometimes we can also find the result that using this technique is not really effective for improving student's reading comprehension. Furthermore , Farinelli (1997) states that one of the reason for using SQR3 because it is effective for helping students in improving the amount of information they retain in reading in any subject area and forcing the student to "prime and pump" before actually beginning the reading. This "priming and pump" includes surveying the material before actually beginning the reading and developing question that reader feels the author may pose and/ or answer. In doing these two steps before actually beginning the reading, the readers begins to form some general ideas on the subject or topic to be read and begins guessing at the author's intention instead of " reading the material cold". He also said that some studies show that SQR3 help to engage the reader's interest in the material and help to improve comprehension of the material.

\section{METHOD}

This research was aimed to find out the effect of using SQR3 method towards reading comprehension for the second year student of Ma Attahzib Gunung Sari in academic year 2015/2016. The research was conducted for a month starting from giving a pre-test, treatment, and post test.

The writer conducted quasi experimental pre-test post-test non-equivalent control group design. Since it was impossible to assign the existing subjects randomly to control and experimental group. The classes and schedules cannot be reorganized and disrupted so it was necessary to use groups as they are already organized into classes; pretest and posttest has administered before and after treatment. Here the writer used SQR3 method as a method to teach reading comprehension for the treatment. This study use a pre-test and post-test design for data collection. The design of the experiment describes as follow : 
In this study, the writer used two group as the samples. In deciding the experimental group and control group, the writer duscussed it with the English classroom teacher. As the result, the writer decides to employ class XI IPA 1 as the experimental group (x) and XI IPA 2 as the control group (y). The writer decided to choose those classes because they were likely to have equal abilities in English lesson. Both of the groups were given different treatments, but tasted by using the same test. In the treatment process, group (x) as the experimental group has treated by using SQR3 method, while group (y) as the control group was not treated in the same way.

In analyzing the data, the writer used a $t$-test. Before using the $t$-test, the writer used some other formulas to find out the deviation score of the experimental group and the control group in the pre-test and the post-test. First of all, the writer obtains all of the pre-test and the post-test scores. To find the deviation score and square deviation score of the experimental and the control group between the pre-test and post-test, the writer used the formula below :

a). The mean deviation and square deviation score for the experimental group $\mathrm{Mdx}$

$$
\begin{aligned}
= & \frac{\Sigma d x}{\mathrm{~N}} \\
& \Sigma \mathrm{x}^{2}=\Sigma \mathrm{x}^{2-\frac{(\Sigma \mathrm{x})^{2}}{N}}
\end{aligned}
$$

b). The mean deviation and square deviation score for the control group

$$
\begin{aligned}
& \text { Mdy }=\frac{\Sigma d y}{\mathrm{~N}} \\
& \Sigma \mathrm{y}^{2}=\Sigma \mathrm{y}^{2-} \frac{(\Sigma \mathrm{y})^{2}}{N}
\end{aligned}
$$

Where :

$\mathrm{M}=$ the mean deviation of each group

$\mathrm{N}=$ subject oof sample

$\mathrm{X}=$ Deviation between pre-test and post -test of experiment group

$\mathrm{Y}=$ Deviation between pre-test and post -test of control group

$\sqrt{ }=$ The root of...

$\Sigma=$ the sum of....

After getting the mean score and the sum of the deviation of individual score in experimental group and control group, the writer used t-test formula as follow :

$$
t=\frac{M d x-M d y}{\sqrt{\left\{\frac{\sum d^{2}+\sum d^{2}}{N x+N y-2}\right\}\left\{\frac{1}{N x}+\frac{1}{N y}\right\}}}
$$


In which:

Mdx : the mean deviation of score of experimental

Mdy : the mean deviation of score of control group

$\mathrm{dx} / \mathrm{dy}$ : the deviation of $\mathrm{X} 1 / \mathrm{Y} 1$ and $\mathrm{X} 2 / \mathrm{Y} 2$

$\sqrt{ } \quad:$ the root of...

: the square deviation of pre-test and post-test of experimental group

$\mathrm{N} \quad$ : number of sample

Nx : number of sample of experimental group

Ny : number of sample of control group

$\Sigma \quad$ : the sum of...

(Arikunto,2010:354)

To find the degree of freedom, the writer used the formula as follow:

Where:

$$
\mathrm{df}=(\mathrm{Nx}+\mathrm{Ny})-2
$$

df : degree of freedom

$\mathrm{Nx} \quad$ : number of sample of experimental group

Ny $\quad$ : number of sample of control group

\section{FINDINGS AND DISCUSSION}

\section{Findings}

In collecting the data,the writer conducted three steps: pre-test,treatment and posttest. On the first meeting,the writer gave a pre-test to students to warm up student's current reading comprehension ability. Then ,the writer gave some treatment to the students. In the treatment process, both of group were treat differently. The experimental group were treat by using SQR3 method, while the control group were not treat by the SQR3 method as a comparator to see wether the SQR3 method is effective or not. The last step in gathering the data was post-test. This test was aimed to find out the result wether the use of SQR3 method is able to make a progress on student's reading comprehension after giving a treatment. The test is the same as the one given in the pre-test.

In this chapter,the writer also presents a discussion to answer the research question that has been formulated earlier "Is SQR3 method is effective in teaching in student's reading comprehension, when it is used to teaching the student's reading comprehension on the second year students of MA At-tahzib Gunung sari in academic year 2015/2016", and to prove the Ha hypothesis "SQR3 method is effective to be used in attempting student's reading comprehension" in confidence level of . $05(95 \%)$ or. $01(99 \%)$.

In order to answer the research question and prove the Ha hypothesis, the writer analyzed the data gained in pre-test and post-test scores of experimental group and control group by showing the statistical computation including the colculation of 
mean score of both the experimental and the control group, and the calculation of the t-test to compare the significance.

\section{Data Distribution}

After getting the data, the writer then computed the pre-test and the post-test scores of both groups. Here is the result of the experimental and the control group.

Table 01. Student's pre-test and post-test scores of experimental group.

\begin{tabular}{|c|c|c|c|}
\hline No & Subject & $\begin{array}{l}\text { Pre-test } \\
\text { (X1) }\end{array}$ & $\begin{array}{l}\text { Post-test } \\
(\mathrm{X} 2)\end{array}$ \\
\hline 1 & Ahmad multazam ibrahim & 52 & 76 \\
\hline 2 & Azmil umaro & 52 & 84 \\
\hline 3 & Andra rizki kusuma & 36 & 70 \\
\hline 4 & Andre syah pahlefi & 60 & 84 \\
\hline 5 & Amelia safitri & 56 & 80 \\
\hline 6 & Arif maulana & 56 & 84 \\
\hline 7 & Bima satriawan & 52 & 80 \\
\hline 8 & Dodi setia pratama & 36 & 60 \\
\hline 9 & Dinda ayuni & 52 & 84 \\
\hline 10 & Dea ananda & 48 & 72 \\
\hline 11 & Galang saputra & 52 & 72 \\
\hline 12 & Hizzbul azzam rifa'i & 60 & 84 \\
\hline 13 & Ismayadi & 68 & 88 \\
\hline 14 & Mawazzinal qisto & 64 & 80 \\
\hline 15 & Muhammad ali firdaus & 80 & 92 \\
\hline 16 & Riski putra ahmad & 52 & 80 \\
\hline 17 & Ramadan putra & 52 & 80 \\
\hline 18 & Riki umar hamdun & 52 & 88 \\
\hline 19 & Ridho al-fairus & 52 & 82 \\
\hline 20 & Syarif kadafi & 44 & 60 \\
\hline 21 & Kartika putri & 52 & 68 \\
\hline 22 & Kenli lia hamdani & 44 & 64 \\
\hline 23 & Keza arianto & 44 & 64 \\
\hline 24 & Indana fitri & 52 & 76 \\
\hline 25 & Angga fahrul hermanto & 52 & 72 \\
\hline \multirow{2}{*}{20} & Juhairiah & 52 & 80 \\
\hline & Sum & 1372 & 1988 \\
\hline \multicolumn{2}{|r|}{ Higher Score } & 80 & 84 \\
\hline \multicolumn{2}{|r|}{ Average score } & 52.76 & 76.46 \\
\hline \multicolumn{2}{|r|}{ Lowest score } & 36 & 60 \\
\hline
\end{tabular}


Table 02. Student's pre-test and post-test scores of control group

\begin{tabular}{|c|c|c|c|}
\hline No & Subject & $\begin{array}{l}\text { Pre-test } \\
\text { (X1) }\end{array}$ & $\begin{array}{c}\text { Post-test } \\
\text { (X2) }\end{array}$ \\
\hline 1 & Azkia sisriani & 80 & 88 \\
\hline 2 & Aprianti & 36 & 36 \\
\hline 3 & Arsil azim & 48 & 48 \\
\hline 4 & Eva rusdiana & 64 & 88 \\
\hline 5 & Fathul aziz & 36 & 48 \\
\hline 6 & Fitriani & 48 & 36 \\
\hline 7 & Husnul hotimah & 24 & 36 \\
\hline 8 & Herdin & 48 & 60 \\
\hline 9 & Herlina & 52 & 56 \\
\hline 10 & Haerunnisa & 60 & 78 \\
\hline 11 & Khairil anwar & 60 & 76 \\
\hline 12 & L risman hakim & 36 & 64 \\
\hline 13 & Mira juana & 36 & 36 \\
\hline 14 & Mimtah hannah & 56 & 56 \\
\hline 15 & Muhammad albi & 44 & 36 \\
\hline 16 & Muhammad hidayat & 44 & 48 \\
\hline 17 & Maula riza & 52 & 72 \\
\hline 18 & Muhammad humaidi & 44 & 80 \\
\hline 19 & Moh ridwan & 36 & 40 \\
\hline 20 & Nurrahman & 28 & 36 \\
\hline 21 & Rusdi tahir & 68 & 75 \\
\hline 22 & Silvia apriningsih & 36 & 48 \\
\hline 23 & Sukran hadi & 60 & 72 \\
\hline 24 & Rauhul & 44 & 68 \\
\hline 25 & Wasila wati & 36 & 36 \\
\hline 26 & Zaenal abidin & 36 & 64 \\
\hline \multicolumn{2}{|r|}{ Sum } & 1232 & 1481 \\
\hline \multicolumn{2}{|r|}{ Higher Score } & 80 & 88 \\
\hline \multicolumn{2}{|r|}{ Average score } & 47.38 & 56.96 \\
\hline & Lowest score & 28 & 36 \\
\hline
\end{tabular}

\section{Data Computation}

After describing the data distributions, the next step is to calculate the deviation score and the square deviation score of pre-test and post-test of both groups. The data is shown in the tables below;

Table 03. the deviation and square deviation score of experimental group

\begin{tabular}{|l|l|l|l|l|l|}
\hline No & Subjects & $\begin{array}{l}\text { Pre-test } \\
(\mathrm{X} 1)\end{array}$ & $\begin{array}{l}\text { Post-test } \\
(\mathrm{X} 2)\end{array}$ & $\begin{array}{l}\text { Deviation } \\
\text { score }(\mathrm{dx})\end{array}$ & $\begin{array}{l}\text { Square } \\
\text { deviation }\end{array}$ \\
\hline
\end{tabular}




\begin{tabular}{|l|l|c|c|c|c|}
\hline & & & & & score $\left(\mathrm{dx}^{2}\right)$ \\
\hline 1 & Ahmad multazam ibrahim & 52 & 76 & 24 & 576 \\
\hline 2 & Azmil umaro & 52 & 84 & 32 & 1024 \\
\hline 3 & Andra rizki kusuma & 36 & 70 & 34 & 1156 \\
\hline 4 & Andre syah pahlefi & 60 & 84 & 24 & 576 \\
\hline 5 & Amelia safitri & 56 & 80 & 24 & 576 \\
\hline 6 & Arif maulana & 56 & 84 & 28 & 784 \\
\hline 7 & Bima satriawan & 52 & 80 & 28 & 784 \\
\hline 8 & Dodi setia pratama & 36 & 60 & 24 & 576 \\
\hline 9 & Dinda ayuni & 52 & 84 & 32 & 1024 \\
\hline 10 & Dea ananda & 48 & 72 & 24 & 576 \\
\hline 11 & Galang saputra & 52 & 72 & 20 & 400 \\
\hline 12 & Hizzbul azzam rifa'i & 60 & 84 & 24 & 576 \\
\hline 13 & Ismayadi & 68 & 88 & 30 & 900 \\
\hline 14 & Mawazzinal qisto & 64 & 80 & 26 & 676 \\
\hline 15 & Muhammad ali firdaus & 80 & 92 & 12 & 144 \\
\hline 16 & Riski putra ahmad & 52 & 80 & 28 & 784 \\
\hline 17 & Ramadan putra & 52 & 80 & 28 & 784 \\
\hline 18 & Riki umar hamdun & 52 & 88 & 36 & 1296 \\
\hline 19 & Ridho al-fairus & 52 & 82 & 30 & 900 \\
\hline 20 & Syarif kadafi & 44 & 60 & 16 & 256 \\
\hline 21 & Kartika putri & 52 & 68 & 16 & 256 \\
\hline 22 & Kenli lia hamdani & 44 & 64 & 20 & 400 \\
\hline 23 & Keza arianto & 44 & 64 & 20 & 400 \\
\hline 24 & Indana fitri & 52 & 76 & 24 & 576 \\
\hline 25 & Angga fahrul hermanto & 52 & 72 & 20 & 400 \\
\hline 26 & Juhairiah & 52 & 80 & 28 & 784 \\
\hline & Sum & 1372 & 1986 & 652 & 17184 \\
\hline
\end{tabular}

Table 04. the deviation and square deviation score of control group

\begin{tabular}{|l|l|c|c|c|c|}
\hline No & Subjects & $\begin{array}{l}\text { Pre-test } \\
\text { (Y1) }\end{array}$ & $\begin{array}{l}\text { Post-test } \\
\text { (Y2) }\end{array}$ & $\begin{array}{l}\text { Deviation } \\
\text { score (dy) }\end{array}$ & $\begin{array}{l}\text { Square } \\
\text { deviation } \\
\text { score (dy } \mathbf{~}^{\mathbf{}}\end{array}$ \\
\hline 1 & Azkia sisriani & 80 & 88 & 10 & 100 \\
\hline 2 & Aprianti & 36 & 36 & 0 & 0 \\
\hline 3 & Arsil azim & 48 & 48 & 0 & 0 \\
\hline 4 & Eva rusdiana & 64 & 88 & 24 & 576 \\
\hline 5 & Fathul aziz & 36 & 48 & 12 & 144 \\
\hline 6 & Fitriani & 48 & 36 & -12 & 144 \\
\hline 7 & Husnul hotimah & 24 & 36 & 12 & 144 \\
\hline 8 & Herdin & 48 & 60 & 12 & 144 \\
\hline 9 & Herlina & 52 & 56 & 4 & 16 \\
\hline
\end{tabular}




\begin{tabular}{|l|l|c|c|c|c|}
\hline 10 & Haerunnisa & 60 & 78 & 18 & 324 \\
\hline 11 & Khairil anwar & 60 & 76 & 16 & 256 \\
\hline 12 & L risman hakim & 36 & 64 & 28 & 784 \\
\hline 13 & Mira juana & 36 & 36 & 0 & 0 \\
\hline 14 & Mimtah hannah & 56 & 56 & 0 & 0 \\
\hline 15 & Muhammad albi & 44 & 36 & -8 & 64 \\
\hline 16 & Muhammad hidayat & 44 & 48 & 4 & 16 \\
\hline 17 & Maula riza & 52 & 72 & 20 & 400 \\
\hline 18 & Muhammad humaidi & 44 & 80 & 36 & 1296 \\
\hline 19 & Moh ridwan & 36 & 40 & 4 & 16 \\
\hline 20 & Nurrahman & 28 & 36 & 8 & 64 \\
\hline 21 & Rusdi tahir & 68 & 75 & 7 & 49 \\
\hline 22 & Silvia apriningsih & 36 & 48 & 12 & 144 \\
\hline 23 & Sukran hadi & 60 & 72 & 12 & 144 \\
\hline 24 & Rauhul & 44 & 68 & 24 & 576 \\
\hline 25 & Wasila wati & 36 & 36 & 0 & 0 \\
\hline 26 & Zaenal abidin & 36 & 64 & 8 & 64 \\
\hline & Sum & $\mathbf{1 2 3 2}$ & $\mathbf{1 4 8 1}$ & $\mathbf{2 5 1}$ & $\mathbf{5 4 6 5}$ \\
\hline
\end{tabular}

\section{Computing and Analyzing the Mean Score}

After getting the deviation score of pre-test and post-test, the mean score of two groups can be commutated, that was by deviding the total of the deviation score of the total number of sample in a group. It can be formulated as follow;

$M d x=\frac{\Sigma d x}{\mathrm{~N}}$ for the experimental group

$M d y=\frac{\Sigma d y}{\mathrm{~N}} \quad$ for the control group

Where :

Mdx : the mean score of experimental group

Mdy : the mean score of control group

$\mathrm{X} / \mathrm{Y}$ : the deviation score of pre-test and post-test

$\mathrm{N}$ : the number of sample

$\Sigma \quad$ : the sum of...

Thus, the computation of the mean score of the experimental group and control group is shown bellow:

$M d x=\frac{\Sigma d x}{\mathrm{~N}}=\frac{652}{26}=25.07$ 
$M d y=\frac{\Sigma d y}{\mathrm{~N}}=\frac{251}{26}=9.65$

The result of the computation showed that the mean deviation score of the experimental group was 25.07 It was higher than the mean deviation score of the control group which was 9,65 . The difference between the mean score showed that the variable problem (SQR3 method) gave effect to the variable solution (student's reading comprehension ability).

\section{The Computation and Analysis of Corelation of Two Means score}

Regarding on the result mean scores of two groups, it may be true that the experimental group was more succesfull than the control group. Theoritically ,however, the significant of the deviation of mean score and to measure wether the deviation was significant or not, the formula was operated as follows:

1.The mean deviation of experimental group $=25.07$

Square deviation :

$$
\begin{aligned}
\Sigma x^{2} & =\Sigma x^{2}-\frac{(\Sigma x)^{2}}{N} \\
& =17184-\frac{(652)^{2}}{26} \\
& =17184-\frac{425104}{26} \\
& =17184-16350 \\
& =834
\end{aligned}
$$

2. The mean deviation of control group $=9.65$

Square deviation :

$$
\begin{aligned}
\Sigma y^{2}= & \Sigma y^{2}-\frac{(\Sigma y)^{2}}{N} \\
& =5465-\frac{(251)^{2}}{26} \\
& =5465-\frac{63001}{26} \\
& =5465-2423.11 \\
& =3041.9 \\
\mathrm{t} & =\frac{\mathrm{Mdx}-\mathrm{Mdy}}{\sqrt{\left\{\frac{\sum \mathrm{dx}^{2}+\sum \mathrm{dy}^{2}}{\mathrm{Nx}+\mathrm{Ny}-2}\right\}\left\{\frac{1}{\mathrm{Nx}}+\frac{1}{\mathrm{Ny}}\right\}}}
\end{aligned}
$$




$$
\begin{aligned}
& =\frac{25.07-9.65}{\sqrt{\left\{\frac{834+3041.9}{26+26-2}\right\}\left\{\frac{1}{26}+\frac{1}{26}\right\}}} \\
& =\frac{16.07}{\sqrt{\frac{3875}{50} \times \frac{2}{26}}} \\
& =\frac{16,07}{\sqrt{\frac{7750}{1300}}} \\
& =\frac{16.07}{\sqrt{5.96}} \\
& =\frac{16.07}{2.44} \\
& =6.58
\end{aligned}
$$

\section{Discussion}

The result of the t-test computation showed that the score of the t-test was 6.58 . Then the result of the t-test computation was compared by using t-table. Further explanation can be seen in the discussion below;

From the statistical analysis above, the result explained that the mean score of the experimental group was 25.07 It is higher than the mean score of the control group which was 9.65. It showed that SQR3 method can significantly effective for the student's ability in reading comprehension more than the traditional method.

In this study,the writer also applies the degree of freedom (df) interpreted by comparing two critical value: t-test and t-table. The degree of freedom was obtained by using the formula $((\mathrm{Nx}+\mathrm{Ny})-2)((26+26)-2)=50$. The degree of freedom of 50 is 2.00 at confidence level of $0.05(95 \%)$ and 2.66 at confidence level of $.01(99 \%)$.

Table 0.5 the comparison between t-test and t-table

\begin{tabular}{|c|c|c|c|}
\hline \multirow{2}{*}{ t-test } & \multicolumn{3}{|c|}{ t-table } \\
\cline { 2 - 4 } & Df & 0.05 & 0.01 \\
\hline 6.58 & 50 & 2.00 & 2.66 \\
\hline
\end{tabular}

From the comparison above, it is clearly shown that the value of the t-test is higher than the t-table value at the cinfidence level of $0.05(95 \%)$. In short, the use of SQR3 method in teaching can significantly effective for the student's reading comprehension.

Based on the hypothesis testing which states that: If t-test $\geq \mathrm{t}$-table at the confidence level of .05 (95\%) or .01 (99\%), then the Null hypothesis (Ho) which states ' 'the SQR3 method is not effective in teaching student's reading comprehension for the second year students of MA-Attahzib Gunung sari in 
academic year 2015/2016" is rejected. Thus , it should be altered into the alternate hypothesis (Ha) which states "the SQR3 method is effective in teaching student's reading comprehension for the second year students of Ma-Attahzib Gunung sari in academic 2015/2016"

From the analysis and the interperetation above,the writer can conclude that SQR3 method is effective in teaching student's ability in reading comprehension for the second year students of Ma - Attahzib Gunung Sari in academic year 2015/2016. It is proven by the score of mean score of the experimental group which was higher than the mean deviation score of the control group. It is also proven by the t-test which was higher than the t-table at confidence level of .05 (95\%).

The writer also compared this research finding to the previous studies which used the same method, Puspitasari (2010) proved that this method was also effective to be used in improving student's reading comprehension.

Table 0.6 the comparison between the writer and the previous study research finding

\begin{tabular}{|l|l|l|}
\hline Category & Writer's finding & Previous finding \\
\hline Population & 52 & 60 \\
\hline The type of test & $\begin{array}{l}\text { Multiple choice with } \\
\text { four options A,B,C and } \\
\mathrm{D}\end{array}$ & $\begin{array}{l}\text { Multiple choice with } \\
\text { four options A,B,C and } \\
\mathrm{D}\end{array}$ \\
\hline Result & $\begin{array}{l}6.58>2.00(\mathrm{df}=50) \text { on } \\
\text { the level of significance } \\
\text { of } 95 \%\end{array}$ & $\begin{array}{l}3.5769>2.000(\mathrm{df}= \\
58) \text { on the level of } \\
\text { significance of } 95 \%\end{array}$ \\
\hline
\end{tabular}

From the comparison above, it shown that both writers found almost the same result with quite similar number of population. The type of the t-test was also the same (multiple choice with four options A,B,C, and D). Next, the result of both research described that SQR3 method is Effective in teaching student's reading comprehension.

Moreover ,some studies indicate that student's basic knowledge of SQR3 gave impacts on its succesful execution and potential benefits. In addition, Feldt and Hensley (2009) in their article concluded that SQR3 may have utility as a useful learning strategy for learning from textbooks when students are provided with adequate information to utilize it effectively, especially by means of asking questions that truly facilitate learning.

\section{CONCLUSION AND SUGGESTIONS}

After finishing the process of computing and analyzing the data, the writer can conclude that SQR3 method is effective in teaching student's reading comprehension for the second year students of Ma At-tahzib Gunung sari in academic year $2015 / 2016$. The conclusion above is strenghtened by the data below that showed:The students who were treated by SQR3 method was better than the students who were 
not treated with SQR3 method with the computation of the mean score of the experimental group $M x=25,07$ and the control group $M y=9,65$. The value of the $t-$ test (6.85) was also higher than the t-table (2.00) at the cinfidence level of .05 (95\%). It indicates that the Null hypothesis (Ho) which states: the SQR3 method is not effective in teaching student's reading comprehension for the second year students of Ma-Attahzib Gunung Sari” is rejected. Thus, it should be altered into the alternate hypothesis $(\mathrm{Ha})$ which states: "the SQR3 method is effective in teaching student's ability in reading comprehension for the second year students of Ma-Attahzib Gunung Sari in academic year 2015/2016". It can be seen during the implemetation of the method, student's participation was higher than before. The students were able to identify main ideas as well as they obtain more detailed from text. They were more active in answering the teacher questions, they were very cooperative during the implemetation of the method.

\section{REFERENCES}

Harmer, J. (2007). How to Teach English. China: Pearson Education Limited. (on line) http://dessydys.blogspot.com/2011/10/teaching-raeding.html

Henry, A. (2012). How to Boost Your Reading Comprehension by Reading Smarter and More Conscientiously. (on line) http://lifehacker.com/5872944/how-toboost-your-reading-comprehension-by-reading-smarter-and-moreconscientiously

Herlianti, D. 92010). The Effectiveness of SQR3 Method To Teach Reading Comprehension; An Experimental Study In The Second Year Students' of SMPN 1 JENANGAN PONEROGO in Academic Year 2009/2010. Undergraduate Theses from Stain press / 2010-06-19 (on line) http://www.stainponerogo.ac.id

Hornby, AS. (1995). Oxford Advanced Learner's Dictionary of current English: Oxford University Press.

Huber, J. (2004). A closer look at SQR3. Reading Improvement. The Gale Group (on line) http:/goliath.ecnext.com/com2/gi0199-36792/A-closer-look-atSQR3.html

(http://bigfkipunirow2008c.wordpress.com/2011/07/03/the-evvectiviness-ofteaching-speaking-using-presentation-technique-at-man-3-kotakediriacknowledgement-in-the-name-of-alloh-the-beneficent-who-hasgiven-the-researcher-the-most-valuable-bright-thin/

McDonough, J. and Christopher, S. (2003). Materials and Methods in ELT. Second Edition. A Teacher's Guide. United Kingdom. Blackwell Publishing.

Ogle, D. (1986) Strategies for Reading Comprehension $K-W-L$ (on line) http://www.readingquest.org/strat/kwl.html. 
Puspitasari Y. E. (2010). The Effect of Using SQR3R Technique Toward Reading Comprehension Ability for Second Year Students; The Experimental Study for Second Year Students' of SMPN 1 Bodeh Pemalang in the Academic Year 2009/2010. Thesis Strata 1 Program of English Department, Faculty of Teacher Training and Education, Pancasakti University of Tegal. (on line) http://www.perpus.upstegal.ac.id/homr/v2/ index.php?mod=katalog.karyailmiah.show.detail\&barcode $=\mathrm{PB} 1081076$

Robinson, F. (1946). Effective Study (Active Reading and the SQR3 Technique) (on line) http://learning.covcollege.ac.uk/content/jorum study/skill/note /taking/05/methods/06/active.html

Soedarsono. (2004). Speed Reading “Sistem Membaca Cepat dan Efektif”. Jakarta: PT. Gramedia Pustaka Utama.

Smahillah, (2009). The Effectiveness of Teaching Reading Comprehension by Using Jigsaw Technique (on line) http://smahillah.hubpages.com/hub / mamaazaputri2

Webster's New World Collage Dictionary Copyright (C (2010) by Wiley Publishing, Inc, Cleveland, Ohio. Used by arrangement with john Wiley \& Sons. (on line) (http://www.yourdictionary.com/improve)

Young, A. (2007). The SQR3 reading method explained. (on line) (http://www.helium.com/items/352303-the-sqr3-reading-method- explained

Wiersma,William and Jurs Stephen G. 2005.Research Method in Education:An introduction. USA.Pearson Education. 